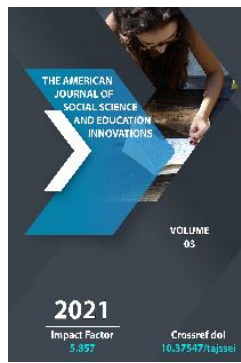

\title{
Systems For The Development Of Primary Education In The Process Of Higher Pedagogical Education
}

\section{Onakhon Mannapovna Jabborova \\ Head Of The Department Of Primary Education, Chirchik State Pedagogical Institute Of Tashkent Region, Uzbekistan}

Journal Website:

http://usajournalshub.c

om/index,php/tajssei

Copyright: Original content from this work may be used under the terms of the creative commons attributes 4.0 licence.

\section{ABSTRACT}

This article analyzes new systems of primary education development in the process of higher pedagogical education.

\section{KEYWORDS}

Primary education, higher pedagogical education, new system, effective systems, international educational traditions, evaluation.

\section{INTRODUCTION}

The process of higher pedagogical education in Uzbekistan is developing in a new system based on national and international levels of education [1]. There are social, pedagogical, methodological and technological bases for the development of primary education. In this regard, in the process of higher pedagogical education, the development of education and training systems in the field of primary education on a new basis remains relevant. 
The Resolution of the Cabinet of Ministers of the Republic of Uzbekistan dated April 14, 2021 No 213 "On measures to further improve the activities of Chirchik State Pedagogical Institute of Tashkent region" sets the task to develop and implement new and effective systems of primary education in higher pedagogical education [2]. The analysis of this Resolution shows that in the process of higher pedagogical education it is possible to form the following new systems of development of primary education:

1. Improving the content and quality of primary education. The introduction of the following new systems of improving the content and quality of primary education in the process of higher pedagogical education will have the expected effect:

- Creation of a system of competition for the content of primary education, with the need to set goals for quality development of primary education from preschool and general secondary education;

- Strengthening the training of highly educated personnel with high knowledge and skills in the field of primary education, in which the training of primary school teachers based on systems such as electronic-modular laboratory, distance learning and computer technology will give the expected effect;

- Introducing innovative clusters of pedagogical education in primary education, with the establishment of "School-laboratory", "Education + practice" laboratories.
2. Improving the effectiveness of teaching and learning methods in primary education. It should be noted that paying attention to the following will give the expected effect:

- Inculcate in the content of education a new national idea of Uzbekistan - humanity, kindness and creativity;

- Popularization and international promotion of the experience of advanced teachers in teaching methods of primary education;

- Relying on electronic-modular teaching methods;

- Involving qualified teachers in primary education who know information and communication technologies and have a thorough knowledge of foreign languages.

3. Introducing advanced foreign experience in primary education. It should be noted that paying attention to the following will give the expected effect:

- Implementing curricula and science programs in the field of primary education undergraduate education on the basis of advanced foreign experience;

- Introducing a master's degree in primary education, attracting undergraduate graduates with the qualities of activity, willpower, leadership and independent thinking;

- Training of bachelor's and master's degree specialists in the field of primary education in a combination of national 
pedagogical experience and international educational traditions.

4. Introducing digital technologies in primary education. Digital technologies are based on the effective use of the capabilities of these information and communication devices. Therefore, it is advisable to pay attention to the following:

- Creation of electronic copies of textbooks and manuals;

- Relying on the principles of conciseness, novelty and comprehensibility in the preparation of educational materials based on state educational standards;

- Establishment of educational and scientific laboratories of primary education.

5. Strengthening international cooperation in primary education. In this case, it is advisable to pay special attention to:

- Use of international evaluation programs (PISA, TIMSS PIRLS) and STEAM standards;

- Updating the forms of teaching and assessment of exact and natural sciences in primary education;

- Introducing joint educational programs in primary education in cooperation with foreign higher education institutions and the organising of internships for students of primary education on a new basis.

It should be noted that in the process of higher pedagogical education, new systems of primary education are clearly and purposefully defined. Therefore, deep mastering and understanding of these systems is required.

The resolution also sets the task of directing students to the pedagogical profession. In this regard, the development of primary education will strengthen the implementation of this task:

- Organizing special "Reading and Mathematical Literacy Classes" for students of grades 3-4;

- Organizing lessons in the primary grades of secondary schools on the basis of an innovative cluster of pedagogical education.

- Cluster development of primary education.

In order to implement these tasks and further develop primary education, a system of basic and additional specialization is being introduced for primary school teachers in the process of graduating from higher education. This means that in the next 3-4 years, the primary school teacher will not only acquire the basics of the main specialization in primary education, but also have additional professional competence in a particular subject taught in primary education.

Thus, a new system of primary education development is perceived in the process of higher pedagogical education. It is understood that this system is deeply mastered by the participants of the process of higher pedagogical education. To do this, it would be expedient to get acquainted with the new tasks related to education and to focus on mastering the tasks set out in the decision we analyzed [3]. 


\section{REFERENCES}

1. Ўзбекистон Республикаси Президентининг 2020 йил 27 февралдаги “Педагогик таълим сохасини янади ривжлантириш чора-тадбирлари тўғрисида"ги Қарори. // www. ziyonet.uz.

2. Ўзбекистон Республикаси Вазирлар Махкамасининг 2021 йил 14 апрелдаги “Тошкент вилояти Чирчиқ давлат педагогика институти фаолиятини янада такомиллаштириш чора-тадбирлари тўғрисида"ги Қарори. // www. ziyonet.uz.

3. Jabborova Onakhon Mannapovna. (2019). Psycholocial and pedagogical foundations of the formation of the artistic perception of students in secondary schools. European journal of research and reflection in educational sciences, 7(10), 914.

4. Jabborova Onakhon Mannapovna, Ismoilova Dilafruz Mukhiddinovna. (2020, may). Optimation of primary education. ACADEMICIA: An international multidisciplinary research journal, 10(5), 1229-1232.

5. MardonovSh.K.,Jabbarova O.M.. Objectives of the lessons of visual arts in primary school. Academic research in educational sciences, Issue 3, 2020, pp 862-870.

6. Mardonov Shukurullo Kuldashevich, Khujamkulov Umid Negmatovich, Botirova Shakhlo Isomiddinovna, Shermatova Umida Safaevna. The end to educate young people with the spirit of patriotism in the context of globalization. Journal of Critical Reviews, Malaysia, 2020, Vol.7, Issue 12, pp 166-169.

7. Mardonov Shukurullo Kuldashevich, Quttibekova Guljan Tulepbaevna. Structure and Mechanisms of Action of
The Educational Cluster. International journal of Psychosocial Rehabilitation, United Kingdom, 2020, Issue 07, pp. 81048111.

8. Jabborova Onakhon Mannapovna, Jumanova Fotima Uralovna, Mahkamova Shohida Rahmatullayevna. (2020). Formation of artistic perception of future teachers. International journal of pssycological and rehabilitation, 24(4), 4087-4095.

9. Mamadaliyev K.R., Jabborova O.M., Umarova Z.A., Abdullaeva B.P. Creation of a New Generation of Teaching Literature A Requirement of Modernity // SCOPUS International Journal of Psychosocial Rehabilitation, Vol. 24, Special Issue 1, 2020.

10. Жабборова Онахон Маннаповна, Ташпулатова Дилором Мукимовна, Бошланғич синф ўқитувчиларига қўйиладиган талаблар. Academic research in educational sciences, Issue 3, 2021, pp 575-582

11. Gulyamova X. Boshlang'ich sinflarda o'qish darsidan umumlashtiruvchi darslarni tashkil etish. Academic research in educational sciences, Volume 2, Issue 1 , 2021, pp 1052-1060

12. Жабборова О.М., Умарова З.А. Тарбия фанини кластер усулида ўқитишда педагогик конфликтларни бартараф этиш. Academic research in educational sciences, Issue 1, 2021, pp 582-587.

13. Жабборова О.М., Чимпулатова Ч.Д. Бошланғич таълимда Тарбия фанининг кластер усулида ўқитилиши. Academic research in educational sciences, Issue 1 , 2021, pp 562-566.

14. Жабборова О.М., Ташпулатова А.М. Ўзбекистон янги мафкурасининг педагогик талқини. Academic research in 
educational sciences, Volume 2, Issue 3, 2021, pp 584-589.

15. Умарова 3.А. Бошланғич таълим дидактикаси. Academic research in educational sciences, Issue 2, 2021, pp 556562.

16. Ochilov Fariddunlzatulloyevich, Methods of teaching natural sciences to primary school pupils on the basis of a competent. Palarch's Journal of Archaeology Of Egypt/ Egyptology 17(6) (2020), ISSN 1567214х. 14520-14539бетлар.

17. OchilovFariddun "Atrofimizdagi

"Tabiatshunoslik" Izatulloyevich, kompetensiyaviy yondashuv asosida tashkil etish jarayonini modellashtirish. The Journal of Academic Research in Educational Sciences, 1(4), (2020). ISSN 2181-1385. VOLUME 1, ISSUE 4. December 2020. Scientific Journal Impact Factor (SJIF) 2020: 4.804. Academic Research, Uzbekistan 2020. 624-629бетлар.

18. 18. Abdullaeva B.P. Babaraximova B.P. Pardaev B.P.Using information and communication technologies in teaching process of various primary European Journal of Research and Reflection in Educational Sciences, 8 (10), 67-70. Progressive Academic Publishing, UK www.idpublications.org 14.10.2020

19. Abdullaeva B.P. Abdullaeva F.T. Organization Of Swimming Lessons In Preschool Institutions THE AMERICAN JOURNAL OF SOCIAL SCIENCE AND EDUCATION INNOVATIONS. JULY 2020[ TAJSSEI]322ISSN (e):2689-100X DOI: https://doi.org/10.37547/tajssei/Volumeo2 I ssue 07-42

20. Abdullayeva, B. P., \& Babaraximova, B. P. (2020). MAKTABGACHA TA'LIM MUASSASASIDA FUTBOL DARSLARINI
TASHKIL ETISH METODIKASI. Academic Research in Educational Sciences http://ares.uz/jurnallar-sahifasi/ares-vol-1no-3-2020

21. ACADEMICIA: An International Multidisciplinary Research Journal https://saarj.com ORGANIZATION AND METHODOLOGY OF CONDUCTING FOOTBALL LESSONS IN A PRESCHOOL INSTITUTION Abdullaeva B.P 650-655 10.5958/2249-7137.2021.00098.7 